\title{
Pelatihan Pengenalan Pakan Kambing Perah di Kelompok Peternak Roudhatul Ghonam Kecamatan Sidamulih Kabupaten Pangandaran
}

\author{
Raden Febrianto Christi ${ }^{*}$, Diky Ramdani ${ }^{2}$, Endah Yuniarti ${ }^{3}$ \\ 1,2,3 Universitas Padjadjaran, Jl. Raya Bandung-Sumedang, Hegarmanah, Jatinangor, Hegarmanah, \\ Kec. Jatinangor, Kabupaten Sumedang, Jawa Barat 45363 \\ Email: raden.febrianto@unpad.ac.id ${ }^{1 *}$
}

\begin{abstract}
ABSTRAK
Peternak harus mengenal jenis pakan yang biasa diberikan kepada ternak supaya menghasilkan produksi yang baik. Pakan berupa hijauan, leguminosa, dan konsentrat umumnya diberikan kepada ternak kambing perah. Tujuan pengabdian adalah memberikan pengetahuan tentang pakan kambing perah di Kelompok Peternak Roudhatul Ghonam Sidamulih Pangandaran. Pengabdian ini telah dilaksanakan di kelompok ternak Roudhatul Ghonam Kecamatan Sidamulih Kabupaten Pangandaran yang diikuti oleh peserta berjumlah 30 peserta dengan berbagai tingkatan usia. Metode pelaksanaan dengan cara memberikan penyuluhan kepada para peternak dengan pengenalan berbagai pakan untuk kambing perah. Tahapan dimulai dengan sebaran kuisioner pre test sebelum kegiatan dilakukan dengan 10 pertanyaan yang diajukan, pemaparan materi pengenalan pakan, penyebaran kuisioner post test kepada peserta dan diakhiri dengan sesi tanya jawab peserta dan narasumber. Kemudian mengenalkan pakan berupa hijauan seperti rumput gajah, raja, gamal, kaliandra dan ampas tahu yang bisa diberikan dengan potensi ketersediaan diwilayahnya, konsentrat serta teknologi pakan hasil fermentasi berupa silase. Hasil menunjukkan bahwa pengetahuan tentang pakan meningkat di tingkat peternak berdasarkan pre test dan post test sehingga diharapkan dengan ilmu dan pengetahuan tersebut produktivitas ternaknya tinggi dengan pemberian pakan yang terbaik.
\end{abstract}

Kata kunci: Pakan; Kambing Perah; Kelompok Ternak Roudhatul Ghonam; Kabupaten Pangandaran

\section{ABSTRACT}

Farmers must know the types of feed that are usually given to livestock to produce good production. Feed in the form of forage, legume, and concentrate is generally given to dairy goats. This service aims to provide knowledge about dairy goat feed in the Roudhatul Ghonam Farm Sidamulih Pangandaran. This service was carried out in the Roudhatul Ghonam farm, Sidamulih District, Pangandaran Regency, where 30 participants of various ages attended. The implementation method is by providing counseling to breeders with the introduction of various feeds for dairy goats. The stages began with the distribution of pre-test questionnaires before the activity was carried out with ten questions being asked, presentation of feed introduction material, distributing post-test questionnaires to participants, and ended with a question and answer session between participants and resource persons. Then introduce feed in the form of forages such as elephant grass, king grass, Gamal, calliandra, and tofu dregs that can be provided with potential availability in the region, concentrate and fermented feed technology the form of silage. The results showed that knowledge about feed increased at the farmer level based on the pre-test and post-test. It is expected that with this knowledge and knowledge, the productivity of livestock is high by providing the best feed.

Keywords: Feed; Dairy Goats; Roudhatul Ghonam Farm; Pangandaran Regency 


\section{PENDAHULUAN}

Usaha dalam meningkatkan produktivitas ternak dapat dilaksanakan dengan manajemen tata laksana pemeliharaan yang baik. Produksi daging atau susu yang berkualitas sangat dipengaruhi oleh banyak faktor diantaranya adalah faktor internal dan eksternal dari ternak tersebut. Kebutuhan gizi untuk seekor ternak khususnya kambing perah perlu diketahui pada setiap periode hal ini untuk menunjang produksinya agar dapat terpenuhi. Pakan merupakan makanan yang dapat diberikan pada ternak yang umumnya berupa hijauan dan konsentrat. Hijauan yang tumbuh liar atau dibudidayakan kadangkala tidak banyak diketahui oleh peternak tentang manfaat kandungan nutrient yang terkandung dalam bahan serta sistem pemberianya pada ternak. Hijauan yang diberikan berupa rumput-rumputan atau leguminosa yang tinggi kadar karbohidrat atau serat kasar dan protein kasar seperti rumput gajah, rumput raja, gamal, kaliandra, dan dedaunan yang biasanya tumbuh disekitar tempat tinggal yang belum banyak diketahui manfaatnya. Selain hijauan, limbah tanaman pertanian juga dapat diberikan pada ternak secara langsung maupun tidak langsung. Pemberian yang diberikan secara langsung pada ternak artinya pakan tersebut tanpa diberikan perlakuan apapun sehingga kemurnian kandungan nutrienya masih lengkap. Pada proses secara tidak langsung pakan berupa hijauan dapat dilakukan pengolahan terlebih dahulu agar masa simpan relatif panjang, mempertahankan nutrient dalam bahan, bahkan palatabilitas. Teknologi pengolahan pakan dapat melalui proses silase dimana hijauan diawetkan dengan cara fermentasi secara anaerob melalui serangkaian aktivitas bakteri penghasil asam laktat dan waktu panen kurang lebih 21 hari. Hal tersebut membuat peternak ingin lebih banyak mengetahui tentang pengenalan pakan serta olahanya.

Kabupaten Pangandaran seperti halnya wilayah priangan timur mempunyai iklim tropis, suhu rata-rata berkisar antara $26^{\circ} \mathrm{C}-27^{\circ} \mathrm{C}$ dengan suhu minimum $24^{\circ} \mathrm{C}$ dan suhu maksimum $30^{\circ} \mathrm{C}$. Kelembaban udara bervariasi antara $85 \%$ hingga $89 \%$. Curah hujan berkisar antara 1500-4000 mm/tahun (Kharisma dan Triwardani, 2016). Kondisi demikian menyebabkan hijauan melimpah banyak di wilayah ini. Selain itu, sektor peternakan berkembang cukup pesat hal ini terbukti dengan adanya kelompok ternak khususnya kambing perah yang berada diwilayah Desa Sidamulih. Kelompok ternak yang menamai Roudhatul Ghonam memiliki jumlah kelompok ternak kurang lebih dari 30 orang dengan rata-rata jumlah kepemilikan ternak 10-60 ekor dengan berbagai varietas jenis kambing seperti saaenen, senduro, peranakan etawah, dan jawa randu. Walaupun kelompok ternak tersebut cukup berkembang dengan baik dari sisi pengelolaan atau manajemen tetapi masih 
terdapat kekurangan dalam pemahaman pengenalan jenis pakan serta pengolahanya yang terbaik untuk diberikan pada ternak kambing dwiguna yaitu daging dan susu agar dihasilkan produksi tinggi. Oleh karena itu, kondisi demikian diperlukan pemberian materi atau penyuluhan terhadap peternak mengenai pengenalan berbagai jenis pakan yang baik untuk ternak kambing perah di Desa Sidamulih Kabupaten Pangandaran.

\section{METODE}

Kegiatan pengabdian ini dilaksanakan di Kelompok Ternak Roudhatul Ghonam Kecamatan Sidamulih, Kabupaten Pangandaran Jawa Barat. Penyuluhan materi pakan kambing perah kepada 30 peternak telah dilaksanakan pada bulan oktober 2020. Metode yang digunakan adalah metode penyuluhan berupa ceramah/ penyuluhan tentang pakan dengan mengenalkan berbagai hijauan, leguminosa dan teknologi pengolahan berupa silase. Rangkaian materi yang diberikan dapat dilihat pada tabel 1.

Tabel 1. Rangkaian Materi

\begin{tabular}{|c|c|c|c|}
\hline No & Materi Pembekalan & $\begin{array}{c}\text { Metode } \\
\text { Pelaksanaan }\end{array}$ & Tujuan \\
\hline 1 & $\begin{array}{l}\text { Sosialiasi Pengenalan pakan } \\
\text { ternak kambing perah berupa } \\
\text { hijauan dan konsentrat } \\
\text { dengan komposisi dan } \\
\text { perbandingan kebutuhan } \\
\text { pakan yang diberikan pada } \\
\text { setiap periode ternak }\end{array}$ & Penyuluhan & $\begin{array}{l}\text { Memberikan pengetahuan } \\
\text { kepada peternak tentang } \\
\text { macam bahan pakan, } \\
\text { kandungan nutrient bahan } \\
\text { pakan serta perbandingan } \\
\text { pemberian pakan pada ternak } \\
\text { kambing perah }\end{array}$ \\
\hline 2 & $\begin{array}{l}\text { Sosialisasi pemberian pakan } \\
\text { ternak kambing perah } \\
\text { bagaimana pola pemberian } \\
\text { pakan yang baik }\end{array}$ & Penyuluhan & $\begin{array}{l}\text { Memberikan pengetahuan } \\
\text { kepada peternak bagaimana } \\
\text { pola atau pengaturan } \\
\text { pemberian pakan yang baik }\end{array}$ \\
\hline 3 & $\begin{array}{l}\text { Sosialisasi pengenalan } \\
\text { pengawetan hijauan pakan } \\
\text { seperti pembuatan pakan } \\
\text { fermentasi (silase) }\end{array}$ & Penyuluhan & $\begin{array}{l}\text { Memberikan pengetahuan } \\
\text { lebih tentang makanan ternak } \\
\text { yang diawetkan (teknologi } \\
\text { pengolahan pakan) }\end{array}$ \\
\hline
\end{tabular}

Langkah awal kegiatan pengabdian antara lain melakukan pengisian kuisioner sebelum (Pre test) oleh peternak dengan mengisi pertanyaan yang diajukan, kemudian melakukan penyuluhan tentang pengenalan pakan, tanya jawab dan diakhiri dengan pengisian kuisoner (Post test) untuk melihat atau mengukur pengetahuan dan antusias masyarakat akan pemahaman materi yang telah diberikan. 


\section{HASIL, PEMBAHASAN DAN DAMPAK}

Pakan merupakan makanan yang diberikan pada hewan ternak ruminansia atau non ruminansia (Parakkasi, 1999). Hewan ruminansia seperti sapi, domba dan kambing dapat diberikan pakan berupa hijauan dan konsentrat. Dalam menunjang kebutuhan hidup pokoknya sebagai peternak harus mengetahui keseimbangan gizi yang dibutuhkan ternak agar dihasilkan performa yang baik (Syam dkk., 2016). Di sisi lain, para peternak yang berada di Kelompok ternak kambing Roudhatul Ghonam belum sepenuhnya memiliki pengetahuan tentang pakan. Berikut adalah hasil dari proses penyebaran kuisioner kepada para peternak sebelum (pre test) dan sesudah (post test) dalam bentuk diagram.
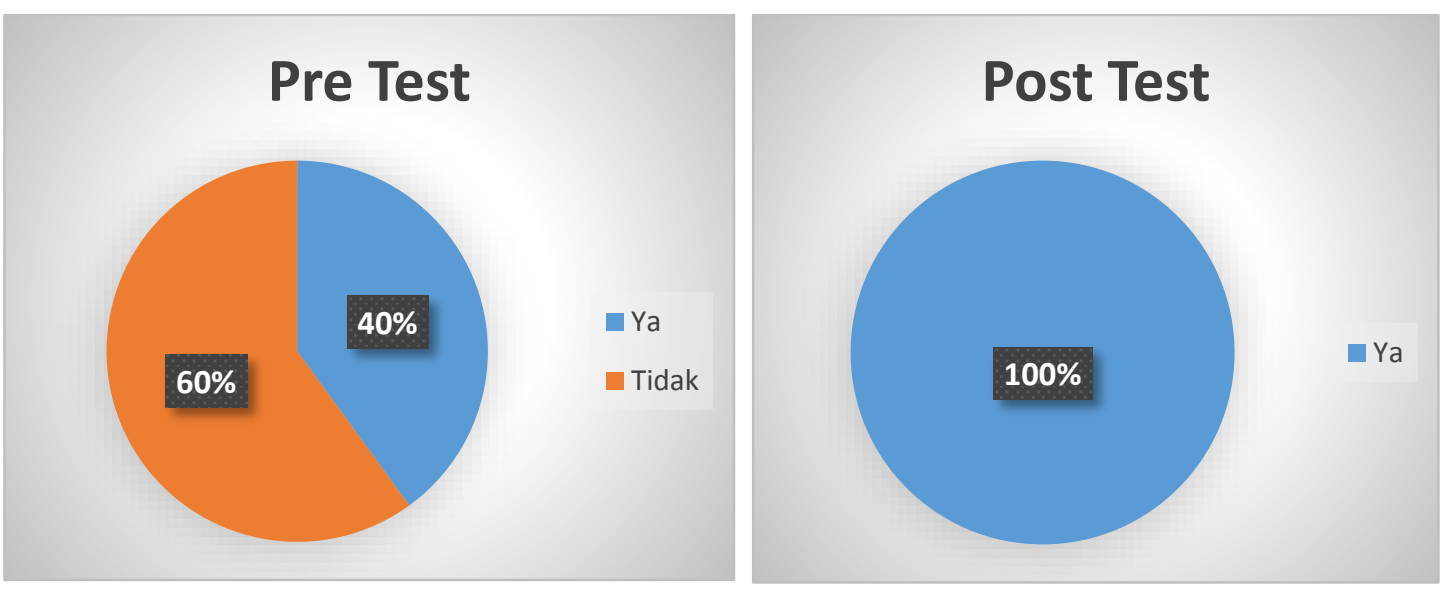

Gambar 1A. Diagram Pre Test dan Gambar 1B Diagram Post Test

Pada diagram 1 hasil pre test menunjukkan bahwa 60\% (18 peternak) memiliki pengetahuan tentang pakan untuk ternak kambing perah sedangkan 40\% (12 peternak) tidak memilikinya. Pengetahuan yang dimiliki oleh peternak dengan persentase $60 \%$ secara umum mengetahui jenis-jenis pakan yang biasa diberikan diantaranya rumput lapang, rumput potong, leguminosa dan konsentrat. Selain mengetahui jenis pakan, juga mengetahui golongan sumber bahan pakan yang termasuk golongan sumber karbohidrat, protein, lemak, vitamin, dan mineral. Menurut Tillman dkk (1991) bahwa pakan harus mengandung nutrient yang tinggi dan memiliki kecukupan gizi untuk kehidupan pokok ternak. Pengetahuan yang dimiliki oleh peternak tersebut diperoleh dari kegiatan pelatihan atau penyuluhan dari instansi pemerintah juga memperoleh informasi dari media cetak dan non cetak seperti internet. Pakan jenis rumput atau leguminosa yang diberikan pada kambing perah di Kelompok Roudhatul Ghonam adalah rumput gajah, daun jagung, daun gamal, batang pisang, ampas tahu serta konsentrat. Rian dkk (2015) melaporkan bahwa pakan kambing perah umumnya diberikan hijauan dan konsentrat. 
Nilai persentase $40 \%$ (pada Diagram 1) menunjukkan pengetahuan peternak di Roudhatul Ghonam tidak sepenuhnya memiliki pengetahuan tentang pakan kambing perah. Hal ini karena dari 12 peternak tersebut beberapa baru memulai usahanya dan ikut bergabung dengan kelompok ternak sehingga belum memahami tentang pengetahuan pakan. Selain itu, beberapa peternak juga memiliki keterbatasan pengetahuan karena kurangnya menguasai teknologi dalam memperoleh suatu informasi yang berkaitan dengan pakan. Penggolongan pakan berdasarkan jenis serta manfaat seperti karbohidrat, protein, lemak, vitamin dan mineral belum dipahami secara penuh oleh peternak. Menurut Fahrul dan Mukhtarm (2017) bahwa peternak harus mengetahui segala aspek yang berkaitan dengan proses pemeliharaan kambing perah seperti pakan untuk menunjang produksinya.

Hasil post test (Diagram 2) menunjukkan persentase sebesar 100\% (30 peternak) artinya terdapat peningkatan $40 \%$ (12 orang) di kalangan peternak tentang pengetahuan pakan pada kambing perah yang semula hanya 60\% (18 peternak) setelah diberikan penyuluhan di Kelompok Ternak Roudhatul Ghonam. Peningkatan terjadi karena adanya pengaruh dari penyuluhan yang dilakukan di kelompok tersebut. Ilmu pengetahuan yang diberikan kepada peternak dapat tersampaikan dengan baik sehingga mudah untuk dipahami. Hal yang dasar saat awal disampaikan kepada peternak yaitu tentang pengertian pakan. Pakan marupakan jenis makanan yang diberikan kepada ternak. Menurut Saitul dkk (2011) bahwa pakan merupakan jenis makanan yang diberikan kepada ternak berdasarkan golongannya. Kambing perah merupakan ternak ruminansia kecil yang umumnya diberikan pakan berupa hijauan dan konsentrat. Kemudian dilanjutkan dengan penjelasan penggolongan pakan yang termasuk sebagai sumber karbohidrat, protein, lemak, vitamin, mineral. Dalam materi penjelasan ini peternak banyak bertanya karena minimnya pengetahuan terkait kandungan nutrient pada setiap pakan bahkan sampai dengan kandungan zat antinutrisi berbahaya. Yogyantara dkk (2014) melaporkan bahwa pada setiap pakan umumnya mengandung antinutrisi yang dapat membahayakan tubuh ternak sehingga perlu mengetahui proses pengolahan yang baik. Penjelasan lain yang disampaikan saat penyuluhan adalah jenis olahan pakan yang dapat mempertahankan kualitas dari pakan yang diberikan pada ternak. Diharapkan dengan penyuluhan tentang pakan pada peternak kambing perah di kelompok ternak Roudhatul Ghonam mampu mengenali jenis pakan serta meningkatkan kemampuan peternak dalam memberikan pakan agar dihasilkan ternak produktivitas tinggi khususnya dalam menghasilkan susu serta daging (dwiguna) sebagai sumber pangan fungsional yang kaya akan protein. 


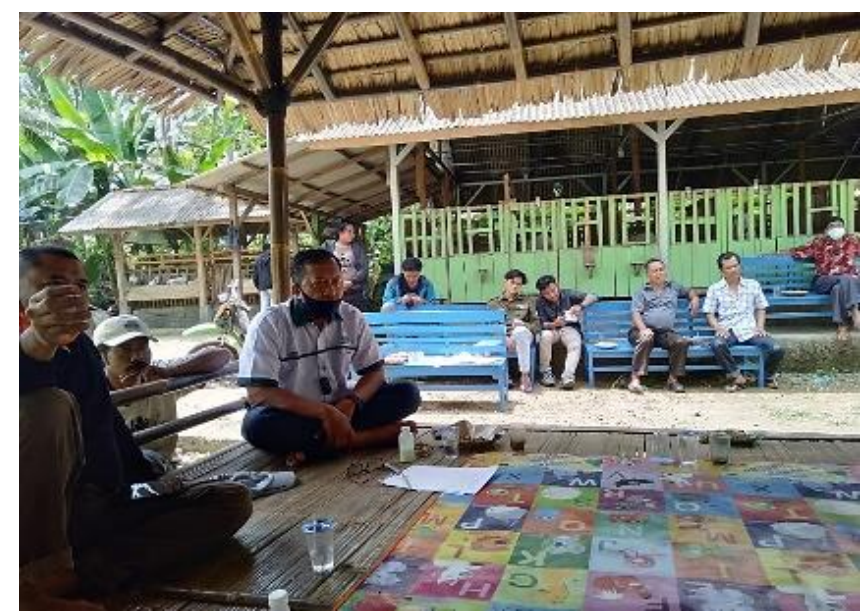

Gambar 1. Diskusi dengan Peternak
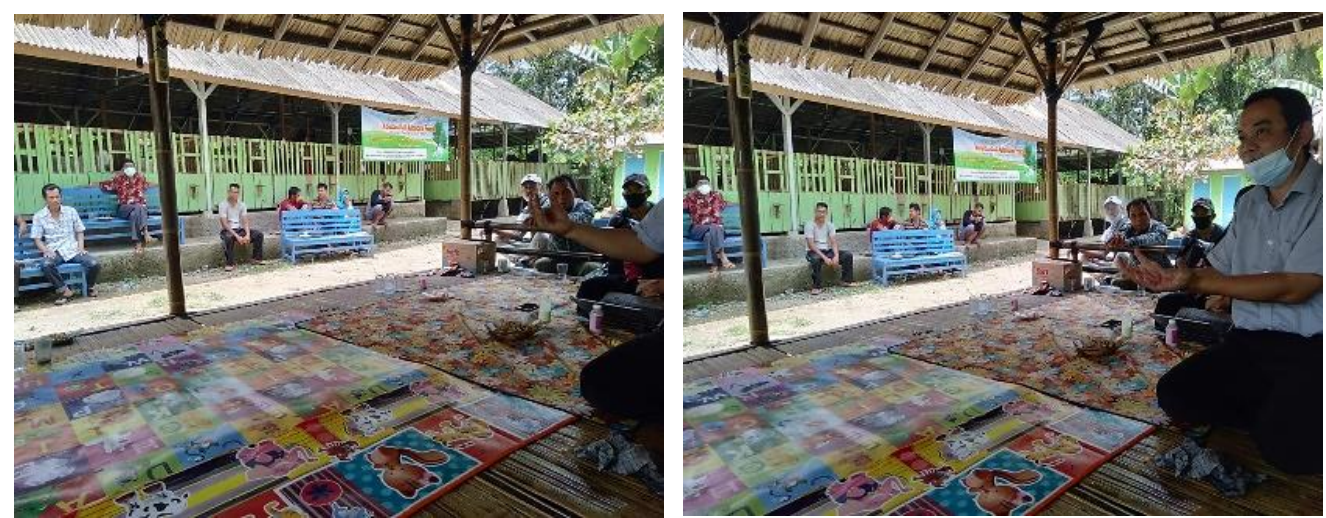

Gambar 2A. Peserta Penyuluhan dan Gambar 2B. Penjelasan Materi Pakan

Sebelum terlaksana kegiatan penyuluhan mengenai pengenalan pakan pada kambing perah di Kelompok Ternak Roudhatul Ghonam Farm Kecamatan Sidamulih Kabupaten Pangandaran peternak masih banyak yang belum mengetahui ilmu serta pengetahuan tentang jenis pakan khususnya untuk ternak kambing perah serta pengolahan pakan dengan teknologi fermentasi. Kegiatan penyuluhan yang dilaksanakan memberikan pengaruh yang besar terhadap peternak terlihat dari antusias mengikuti kegiatan acara. Terselenggaranya kegiatan ini memberikan respon positif dan terlihat hasil dari kegiatan evaluasi terhadap peserta terdapat perubahan yang signifikan khususnya ilmu dan pengetahuan dalam pematerian tersebut serta dapat mengimplementasikanya sebaik mungkin sehingga permasalahan yang terjadi dalam pemeliharaan ternak kambing perah dapat teratasi dengan baik khususnya untuk aspek pakan yang merupakan salah satu faktor dari penentu produktivitas ternak. 


\section{SIMPULAN}

Program penyuluhan tentang pengenalan pakan ternak kambing perah di Kelompok Ternak Roudhatul Ghonam Desa Sidamulih Kabupaten Pangandaran dapat meningkatkan pengetahuan serta wawasan yang luas bagi pada peternak tentang materi pakan. Saran untuk keberlanjutan program ini masih sangat diharapkan oleh para peserta guna meningkatkan kapasitas pengetahuan dalam bidang lainya yaitu Teknis dalam Pembuatan Teknologi Pakan yang bermanfaat bagi masyarakat khususnya peternak di wilayah Desa Sidamulih Kabupaten Pangandaran Provinsi Jawa Barat.

\section{UCAPAN TERIMA KASIH}

Ucapan terima kasih kepada ketua kelompok ternak Roudhatul Ghonam Bapak H. Sidin dan Kepala Desa Sidamulih yang telah memberikan waktu dan tempatnya dalam melaksanakan kegiatan pengabdian kepada masyarakat sehingga dapat terlaksana dengan baik. Tidak lupa juga ucapkan terima kasih kepada mahasiswa angkatan 2017 program studi peternakan Kampus Universitas Padjadjaran Pangandaran yang telah bersedia membantu dalam menyukseskan acara pengabdian kepada masyarakat ini dengan baik.

\section{DAFTAR PUSTAKA}

Fahrul, I dan Mukhtarm M. (2017) Perbaikan Produktivitas Kambing Kacang Melalui Pelatihan Pembuatan Pakan Silase Bagi Warga di Kecamatan Bone Pantai Kabupatan Bone Bolango. Jurnal Abdimas, 10(1), 7-15. doi: http://dx.doi.org/10.36412/abdimas.v10i02.360

Kharisma, B. (2018). Optimalisasi Aksesibilitas Sebagai Percepatan Pembangunan: Studi Kasus Penataan Jalan Di Kabupaten Pangandaran. Optimum: Jurnal Ekonomi Dan Pembangunan, 8(1), 99-118. doi: http://dx.doi.org/10.12928/optimum.v8i1.9014

Parakkasi, A. 1999. Ilmu Nutrisi dan Makanan Ternak Ruminansia. Jakarta. Universitas Indonesia Press.

Rosartio, R., Suranindyah, Y., Bintara, S., \& (Ismaya), I. (2015). Produksi Dan Komposisi Susu Kambing Peranakan Ettawa Di Dataran Tinggi Dan Dataran Rendah Daerah Istimewa Yogyakarta. Buletin Peternakan, 39(3), 180-188. doi: https://doi.org/10.21059/buletinpeternak.v39i3.7986

Saitul, F., Adrizal, Nelson dan Akmal. (2011). Aplikasi teknologi pelleting pelepah sawit sebagaipakanternak di sentra peternakan kambing PEkecamatan bajubang kabupaten Batanghari. Jurnal Pengabdian pada Masyarakat, No. 52 Tahun 2011, ISSN: $1410-0770$. 
Syam, J., A.L Tolleng., dan Umar. 2016. Pengaruh Pemberian Pakan Konsentrat dan Urea Molases Blok (UMB) Terhadap Hematokrit Sapi Potong. Jurnal Ilmu dan Industri Peternakan. 2(2) Hal.1-6. doi: https://doi.org/10.24252/jiip.v2i3.3904

Tillman, A.D., H. Hartadi., S. Reksohadiprodjo., S. Prawirokusumo, dan S. Lebdosoekojo. 1991. Ilmu Makanan Ternak Dasar. Yogyakarta: Gadjah Mada University Pres.

A. P. I. K. D., Y., I. W., S., \& N. N., S. (2016). Pengaruh Level Konsentrat Dalam Ransum Terhadap Komposisi Tubuh Kambing Peranakan Etawah. Majalah Ilmiah Peternakan, 17(3). doi: https://doi.org/10.24843/MIP.2014.v17.i03.p07 